\title{
A FANTASIA NA POLÍTICA: SOFRIMENTO E CULPA NA CONTINGÊNCIA IMPREVISÍVEL DO DESEJO ${ }^{1}$
}

\section{FANTASY IN POLITICS: SUFFERING AND GUILT IN THE UNPREDICTABLE CONTINGENCY OF DESIRE}

\author{
DOI: 10.5533/1984-2503-20091103
}

\section{Márcia Barros Ferreira Rodrigues}

\section{RESUMO}

Nosso objetivo deste trabalho é analisar a partir do romance, "Jóias de Família" de Zulmira Tavares, a relação entre a formação social brasileira no contexto republicano e o "casamento" dos valores burgueses com o fundamentalismo religioso romano-cristão; da ilustração iluminista com a cultura religiosa conservadora e seus efeitos político-ideológicos nos sentimentos inconscientes que nos afetam. O romance será tomado como unidade de análise na perspectiva indiciária de corte psicanalítico e tratará das implicações político-afetivas desses condicionantes nas relações sociais e estrutura psíquica dos personagens no que denominaremos de autoritarismo afetivo. Interessa-nos analisar as fantasias de poder e autoridade contida nas emoções inconscientes dos personagens, sua influência nas permanências culturais de longa duração e o pathos (sofrimento) e culpa presentes na trama. $O$ foco da análise será as tentativas de controle do desejo na conjugalidade e o engaste da ideologia romano-cristã na carona da contingência imprevisível do desejo.

Palavras-chave: Fantasia, política, ideologia, desejo e indiciarismo.

\footnotetext{
${ }^{1}$ Este texto foi produzido originalmente como parte das atividades desenvolvidas nos meus estudos de Pós-Doutorado realizados na Universidade Federal Fluminense (UFF) em 2007, sob a supervisão do Prof. Dr. Gisálio Cerqueira Filho junto ao Programa de Pós-Graduação em Ciência Política (PPGCP) e no Laboratório Cidade e Poder da referida universidade. O texto em questão foi revisado e transformado no artigo ora apresentado.
} 


\section{RESUMEN}

Nuestro objetivo en este trabajo es analisar desde la novela "Jóias de Família" de Zulmira Tavares, la relación entre la formación social brasileña en el contexto republicano y el "casamiento" de los valores burgueses con el fundamentalismo religioso romano-cristiano; de la ilustración iluminista con la cultura religiosa conservadora y sus efectos político-ideológicos en los sentimientos inconscientes que nos afectan. La novela será tomada como unidad de análisis en la perspectiva indiciaria de corte psicoanalítico y tratará de las implicaciones político-afectivas de estos condicionantes en las relaciones sociales y estructura psíquica de los personajes en lo que denominaremos de autoritarismo afectivo. Nos interesa analisar las fantasías de poder y autoridad contenida en las emociones inconscientes de los personajes, su influjo en las permanencias culturales de larga duración y el pathos (sufrimiento) y culpa presentes en la trama. El foco de análisis será las tentativas de control del deseo en la conjugalidad y el engaste de la ideología romano-cristiana juntamente con la contingencia imprevisible del deseo.

Palabras-clave: Fantasía, política, ideología, deseo e indiciarismo.

\section{ABSTRACT}

Our objective in this paper is to analyze, based on Zulmira Tavares' novel, "Jóias de família" ("Family jewels"), the relationship between the Brazilian social background in the republican context and the "marriage" of bourgeois values with the Roman-Christian religious fundamentalism; an enlightened illustration of the conservative religious culture and its ideological and political effects on unconscious feelings that affect us. The novel will be used as the analysis stand-point in the pscychoanalytic indicative perspective and will deal with emotional and political implications of these constraints in social relations and the psychic structures of the characters in what we'll call emotional authoritarism. It's of our interest to analyze fantasies of power and authority contained in the characters' unconscious emotions, its influences on long-lasting cultural tenements and the pathos (suffering) and guilt in the plot. The analysis will focus on the attempts to control marital desire and the 
crimping of the Roman-christian ideology in the wake of the unpredictable contingency of desire.

Key words: Fantasy, politics, ideology, desire and abductive (symptomatic) methodology.

\section{RÉSUMÉ}

Notre objectif est ici d’analyser, á partir du roman “Jóias de Família” (Bijoux de famille) de Zulmira Tavares, la relation entre la formation sociale brésilienne dans le contexte républicain et le «mariage» des valeurs bourgeoises avec le fondamentalisme religieux romano-chrétien et de concepts des Lumières avec la culture religieuse, afin d'en extraire ses effets politico-idéologiques sur les sentiments inconscients qui nous affectent. Le roman sera pris comme unité d'analyse selon la perspective indiciaire d'inspiration psychanalytique. Nous traiterons des implications politico-affectives de ces facteurs de conditionnement dans les relations sociales et la structure psychique des personnages, au sein de ce que nous appelons «autoritarisme affectif ». Nous souhaitons analyser ici les phantasmes de pouvoir et d'autorité contenus dans les émotions inconscientes des personnages, leur influence sur les schémas culturels à long terme, ainsi que la culpabilité et le pathos (souffrance) présents dans la trame du roman. Le point de vue central de l'analyse s'axera autour des tentatives de contrôle du désir dans le cadre conjugal et de l'imbrication de l'idéologie romano-chrétienne quant à la contingence imprévisible du désir.

Mots-clés : phantasme, politique, idéologie, désir et méthode indiciaire.

\section{Introdução}

A escritora Zulmira Ribeiro Tavares em Jóias de Família ${ }^{2}$ oferece-nos uma obra prima do ponto de vista literário. Seu estilo confere ao mesmo tempo densidade e dinâmica à narrativa. Surpreende pela sutileza e crítica ferina que provoca e

\footnotetext{
${ }^{2}$ Tavares, Zulmira Ribeiro (2007). Jóias de Família, Editora: Companhia das Letras.
} 
envolve o leitor na trama. A utilização da linguagem predominantemente metafórica é intencional e produz um efeito de lusco-fusco onde tudo fica subentendido. Os comportamentos caricaturais, dramáticos, cínicos e sórdidos dos personagens, vão pontuando sentimentos que revelam sutilmente as contradições e ambigüidades inclusas no processo de modernização conservadora pela qual passou a cultura política brasileira inscrita na tradição romano-canônica.

A densidade e atualidade dos temas tratados no referido romance tornam possível um estudo das ideologias e uma reflexão sobre a sociedade brasileira contemporânea a partir de suas permanências históricas. Nesse sentido, “Jóias de Família" constitui-se numa excelente unidade de análise para a perspectiva indiciária de corte psicanalítico. Essa perspectiva utiliza a racionalidade do paradigma indiciário de Carlo Ginzburg ${ }^{3}$, ampliando-o ao tratar os indícios enquanto sintomas. Procura interrogar "as práticas, os saberes e os afetos a partir dos matemas da psicanálise e de seu postulado: há falta no Outro". Esse real da psicanálise é buscado "no campo da cultura e investigado a partir da lógica tanto do significante, inscrito na ideologia e nas lutas históricas, bem como na economia do gozo"4.

Nesse sentido, e inspirados em Cerqueira Filho, inferimos que o título do romance condensa por meio da metáfora "jóia", as contradições e ambivalências dos sentimentos inconscientes que informam e conformam o imaginário social brasileiro no que se refere à instituição da família nuclear burguesa e sua permanência patriarcal. Como também aciona a dialética do par contraditório ilusão/alusão, mecanismo principal da interpelação ideológica. No entanto, o romance pode ser lido de forma linear tendo a falsidade e a mentira como tema central, marcado que é por segredos e mistérios indizíveis segundo a tradição conservadora da família burguesa no Brasil, assentada que está no absolutismo afetivo ${ }^{5}$. Diante disso, é preciso destacar que são exatamente as ilusões, falsidades e mentiras, presentes na

\footnotetext{
${ }^{3}$ Ginzburg, Carlo (1989). Mitos, emblemas e sinais: morfologia e história, São Paulo: Companhia das Letras.

${ }^{4}$ Cerqueira Filho, Gisálio (2005). Autoritarismo afetivo: a Prússia como sentimento, São Paulo: Editora Escuta, p.6.

${ }^{5}$ Estamos utilizando essa denominação no sentido empregado pela historiadora Gizlene Neder em seus escritos sobre as relações entre Direito e História e seus efeitos na tradição jurídico-penal luso brasileira. Ou seja, um conjunto de sentimentos/pensamentos baseados no princípio teológico romano-cristão da perfeição.
} 
trama, que aludem às contradições do processo de aburguesamento ocorrido a partir da década de 1930 no Brasil.

A narrativa literária de "Jóias de Família" aborda a família nuclear burguesa e a permanência do patriarcalismo constitutivo do seu padrão conservador, moralista e autoritário. O puritanismo católico é tratado no romance por meio de temas, práticas e rituais consagrados pela ideologia e cultura religiosa que conformam o escopo doutrinário teológico e filosófico da cristandade ocidental e suas repercussões no mundo luso-brasileiro. O cenário escolhido pela autora é São Paulo e tem como pano de fundo o processo de ascensão e decadência de um segmento da burguesia paulistana, no período que vai dos anos 30 até a década o final de 1960. Os temas enfocados por Zulmira ao narrar a saga da personagem principal, Maria Bráulia, são oriundos da ideologia religiosa cristã tais como: o casamento como sacramento, a religiosidade, a sacralidade da família, a virtude feminina alicerçada na obediência ao marido, a moralidade da justiça e do direito canônico; assim como temas transversais relacionados a estes, tais como: o homossexualismo, o adultério, os negócios escusos, o racismo, o preconceito social e o conflito de classe.

Nosso objetivo é analisar a partir de "Jóias de Família", a relação entre a formação social brasileira no contexto republicano e o "casamento" dos valores burgueses com o fundamentalismo religioso romano-cristão; da ilustração iluminista com a cultura religiosa conservadora e seus efeitos político-ideológicos nos sentimentos inconscientes que nos afetam. O romance será tomado como unidade de análise na perspectiva indiciária de corte psicanalítico e tratará das implicações político-afetivas desses condicionantes nas relações sociais e estrutura psíquica dos personagens no que denominaremos de autoritarismo afetivo. Interessa-nos analisar as fantasias de poder e autoridade contida nas emoções inconscientes dos personagens, sua influência nas permanências culturais de longa duração e o pathos (sofrimento) e culpa presentes na trama. $O$ foco da análise será as tentativas de controle do desejo na conjugalidade e o engaste da ideologia romano-cristã na carona da contingência imprevisível do desejo.

Traremos o tema numa interpretação norteada pelas ciências sociais e informada pela psicanálise e pela psicopatologia fundamental. Nossa contribuição é no sentido da constituição de uma experiência, um discurso compartido a respeito 
do pathos psíquico a partir da relação entre pathos, cultura e ideologia, entendendo que o pathos constitui uma subjetividade que é expressão de uma história singular e coletiva simultaneamente. Essa perspectiva, como aponta Berlinck ${ }^{6}$, parte do pressuposto de que o humano é uma espécie psicopatológica, sem ser doente, ou seja, o humano é portador de uma subjetividade e apresenta um aparelho psíquico que incluí uma dimensão inconsciente. A dinâmica desse fenômeno é regida pelo pathos (sofrimento, paixão, passividade).

\section{O enredo de "Jóias de Família”}

O enredo do romance está centrado no relato da vida de Maria Bráulia Munhoz. O foco da narrativa sob o qual se desenvolve a trama é a discussão em torno da falsidade, ou não, de um anel de rubi sangue de pombo supostamente raro e valioso, que fora dado como presente de noivado à Maria Bráulia pelo futuro marido, um juiz de direito por nome Munhoz. A vida de Maria Bráulia é narrada a partir da velhice na condição de viúva sem filhos e decadente que, no entanto, não perde a pompa e nem abre mão da manutenção dos rituais de poder e dominação internalizados e aprendidos no longo processo de socialização e no casamento.

Maria Bráulia Munhoz é filha de uma família rica oriunda da indústria de tecidos, representante da burguesia paulistana dos anos trinta que se casa com Munhoz, juiz de direito, austero, bem de vida, mas não propriamente rico. O casamento é por interesse mútuo. Interessa a Munhoz entrar para o círculo de poder da burguesia paulistana e interessa a família de Maria Bráulia ter um representante do judiciário entre os seus. A entrada de Munhoz é estrategicamente planejada e está simbolizada pelo anel de rubi com o qual presenteia a noiva e que, como o pretendido por este, produz um efeito de poder perante a família de Bráulia. O fato do juiz não ser rico e presentear a noiva com tão valiosa jóia, é visto pela família como uma senha que abre as portas, pelo rito de passagem do casamento, à entrada do juiz na burguesia paulistana de acento aristocrático oriundo das estruturas agrárias da economia brasileira. O recurso literário da narrativa nos conduz ao processo de socialização e aprendizado que vai da "ingênua e piegas

\footnotetext{
${ }^{6}$ Berlinck, Manoel Tosta. (org.). (2005) Obssessiva neurose, São Paulo: Escuta.
} 
Braulinha, à velha "cínica e desempenada dona Brau". Não há linearidade cronológica. Os fatos se misturam e se mesclam no passado e no presente ao sabor das recordações que os acontecimentos despertam na personagem ou são pontuados e esclarecidos pela autora enquanto narradora. Durante o percurso ficamos sabendo que o anel de rubi era falso, que o respeitado juiz era homossexual e mantinha um amante como secretário, que Braulinha foi entregue, como amante, pelo honrado marido, ao joalheiro Marcel, amigo da família e cúmplice do casal. E que este, na condição de amante, presenteia Braulhinha com uma legítima jóia de rubi, no formato de lapidação cabochão (pingente ponte agudo), que alude ao poder fálico e ao desejo sexual embotado pelo casamento branco do casal.

\section{Teoria Política, Psicanálise, Literatura e História}

Acreditamos que a literatura é um campo fecundo para pensar o pathos enquanto afeto ${ }^{7}$ humano, na perspectiva psicopatológica e, as emoções, enquanto manifestação política. Entendemos como Cerqueira Filho ${ }^{8}$, que o afeto é político e que conforma nossas ações muito mais do que o pensamento. Além do que, como já nos informou Lacan ${ }^{9}$, o inconsciente se estrutura como uma linguagem e essa linguagem é pulsional. Assim, buscamos indícios dos elementos da condição humana, na linguagem, partindo do pressuposto de que a linguagem é vida (pulsão) e oferece um riquíssimo material para análise de sintomas sociais, articulando Teoria Política, Psicanálise, Literatura e História. Só a condição humana permite que algo seja pulsional. A pulsão é o operador da sexualidade humana, assim como, o instinto, é o operador da sexualidade animal. Só onde há pulsão pode haver linguagem. A criação, no caso a criação literária, é sempre precedida de um vazio que, entretanto não é nada. O nada que precede a criação não é nada. É um vazio,

\footnotetext{
${ }^{7}$ Afeto não deve ser confundido com emoção. "O afeto contém a emoção, mas não se reduz a ela. 0 afeto é uma força, é uma paixão intensamente excessiva. Podemos dizer que o pathos é um "afetão", ou seja, aquilo que atinge e modifica o sujeito. Nem toda emoção provoca essa mudança". Conferir "Problemas e Perspectivas no Ensino e Pesquisa em Psicopatologia". Palestra proferida pelo Prof. Dr. Manoel Tosta Berlinck no Instituto de Ciências Humanas e Filosofia, no Laboratório de Psicopatologia Fundamental, Psicanálise e Psicossomática da UFF, em 18/05/05.

${ }^{8}$ Cerqueira Filho, Gisálio (2002). Édipo e Excesso. Reflexões Sobre Lei e Política, Porto Alegre: Sérgio Fabris Editor.

${ }_{9}^{9}$ Lacan, Jaques. (1966). Escritos, São Paulo: Editora Perspectiva, 1988.
} 
um buraco que precisa ser preenchido por algo. A pulsão se infiltra aí e pode ter vários destinos, dependendo do percurso em relação ao objeto psíquico sob a qual projeta para se satisfazer ${ }^{10}$. Lacan ${ }^{11}$ denomina esse vazio de objeto a, a falta inerente à condição humana. O lugar da falta instiga o dínamo da busca incessante, causa desejo. Esse é o eixo central da trama em "Jóias de família". A traição do desejo.

Segundo nos informa Julien Philippe, em Abandonarás teu pai e tua mãe ${ }^{12}$. A psicanálise nos informa a existência de três leis diferentes: a lei do bem-estar, a lei do dever e a lei do desejo. Elas não são equivalentes, não se substituem umas às outras. Conforme as circunstâncias da vida, ou bem ocupam seus próprios lugares respeitando a especificidade de cada um, ou bem entram em conflito. A lei do desejo deve então se apagar em proveito de uma das outras duas. É isso que constitui o trágico da existência.

A trama da peça literária em questão aborda exatamente as tentativas de controle do desejo na conjugalidade. Dessa forma, nossa análise vai identificar os efeitos político-afetivos que propiciam o engaste da ideologia romano-cristã, baseada no casamento como sacramento, na carona da contingência imprevisível do desejo, envolvendo necessariamente culpa e pathos (sofrimento).

\section{A cadeia do circuito pulsional em "Jóias de Família”}

Toda saga do romance é narrada sem que percebamos, de imediato, a tensão contínua mantida por meio da ironia que desarma a consciência e prepara o terreno para os sentimentos inconscientes aludidos nos chistes constantes e provocativos. O tom, até certo ponto monocórdio, provoca naqueles, informados pela escuta psicanalítica, uma atenção flutuante na busca da decifração do sintoma.

\footnotetext{
${ }^{10}$ Sobre a discussão da linguagem literária enquanto linguagem pulsional: Lima, Maria Celeste e Faria de Barros (2003). Circuito Pulsional Em Grande Sertão: Veredas. Dissertação defendida no Programa de Pós-Graduação em Letras do CCHN da UFES.

${ }^{11}$ Lacan, Jacques. (1998). O seminário livro 11: os quatro conceitos fundamentais da psicanálise, Rio de Janeiro: Jorge Zahar Editor.

${ }^{12}$ Philippe, Julien (2000). Abandonarás teu pai e tua mãe, Rio de Janeiro: Companhia de Freud.
} 
A discussão inicial do romance gira em torno da falsidade ou não do anel de rubi sangue de pombo. Esse é o pretexto de Zulmira que dá voz a Maria Braúlia e início à trama. A jóia representada pelo anel de rubi é que abre caminho, por deslocamento, para a cadeia do circuito pulsional. O leitor é apanhado de surpresa em uma narrativa que parece já em andamento, engendrada em momento anterior, a respeito do qual ninguém nunca nada saberá. No início há um pouco de suspense e o leitor precisará avançar mais para estabelecer as relações entre a cadeia de significantes presentes na narrativa. Os entrelaçamentos possibilitam várias interpretações, nesse sentido, entendemos que o significante mestre da narrativa é representado pelo cabochão de rubi, sob o qual se desenvolve a cadeia significante. A metáfora jóia, por efeito de deslocamento, representa respectivamente $\mathrm{o}$ anel e 0 cabochão enquanto representantes da representação. Todavia, o significante mestre que comanda toda cadeia pulsional é o cabochão, ou seja, o desejo sexual reprimido no e pelo casamento. É em torno do casamento e das relações familiares e sociais do casal, que circula a pulsão, ou melhor, a linguagem pulsional do texto literário.

$\mathrm{Na}$ teia de relações estabelecidas pelos triângulos amorosos e na cadeia do circuito pulsional desencadeada, estão: o secretário-fisioterapeuta, amante do juiz, a empregada da família Maria Preta e sua sobrinha-neta, afilhada Benedita e o sobrinho-secretário de Bráulia, Julião juntamente com sua mulher Jurema e seu amigo Bento.

O primeiro triângulo é formado pelo casal Munhoz (o juiz e sua esposa, Maria Bráulia) e o amante do juiz, o secretário-fisioterapeuta, cuja invisibilidade é tal, que ele é o único personagem não nomeado. Esse indício é importante porque alude ao segredo do casamento branco e estéril do casal. O fato do amante do juiz não ser nominado representa o desejo homossexual reprimido que, entretanto, retorna à cena e se repete sintomaticamente. O cerne da questão está na referência simbólica ao rubi. Segundo Chevalier e Gheerbant, no Dicionário de Símbolos, o rubi entre outras atribuições simbólicas,

[...] se tornou a pedra dos enamorados, que inebria sem contato. No entanto, a crer no bom prelado é o olho único e avermelhado que têm no meio da testa os dragões e as serpentes fabulosas. É então, chamado de escarbúnculo. Ela 
supera todas as pedras, as mais ardentes, lança raios como um carvão aceso, e cuja luz as trevas não conseguem apagar ${ }^{13}$.

O simbolismo da "pedra que inebria sem contato", alude ao casamento branco e estéril do casal, assim como, o carvão aceso, "cuja luz as trevas não conseguem apagar", alude ao desejo homossexual que, mesmo nas trevas, explode no discurso cifrado. O primeiro triângulo dá origem ao segundo e ambos sustentam a trama e o enredo da estória. É deles que se origina a cadeia de significantes e o circuito pulsional. As jóias de família representadas pelo anel e pelo cabochão aludem respectivamente à homossexualidade reprimida do juiz e a sexualidade embotada de Maria Bráulia. Ambos remetem à culpa cristã que atormenta a todos e indica a vulnerabilidade diante da autoridade instituída de forma autoritária pela ideologia católico-romana que alicerça a família nuclear patriarcal e seu pilar maior, o casamento. Vejamos: o juiz estabelece uma relação sádica e autoritária com o amante e com a esposa, garantido que está na autoridade patriarcal alicerçada no sacramento do matrimônio, na sua condição de homem e, sobretudo, de juiz. Com o secretário-fisioterapeuta Munhoz estabelece uma relação de mando baseada na subserviência alicerçada no anonimato e invisibilidade social deste, e pela sua condição de classe. Com sua esposa a relação autoritária é garantida pelo casamento e pelo paternalismo. Entretanto, essa dominação é dissimulada por um efeito de inversão próprio da ideologia. Maria Bráulia aceitava as mentiras do marido por medo, e aprendeu com ele, a técnica da dissimulação.

Toda a técnica sem dúvida ela aprendera aos poucos, por "contágio", no convívio de anos com o juiz seu marido, muito mais velho, e que sempre fora nesse campo, mestre[...] É um respeitador! [...] pensara imediatamente em seguida e pediu a Deus para voltar sua atenção para o rubi ${ }^{14}$.

Por outro lado, a cadeia significante se estende ao joalheiro Marcel de Souza Armand que, autorizado pelo juiz e por sua condição de gênero, também exerce seu

\footnotetext{
${ }^{13}$ Chevalier, Jean e Gheerbant, Alain (2005). "Rubi", In Dicionário de símbolos. Rio de Janeiro: José Olympio, 2005, p. 792.

${ }^{14}$ Tavares, Zulmira Ribeiro (2007). Op. Cit., p. 22-25.
} 
autoritarismo patriarcal e paternalista sobre Maria Bráulia, "ilustrando-a", como o juiz também o fizera. Para o joalheiro e ourives de descendência francesa e portuguesa, o francês era a língua com a qual ilustrava Maria Bráulia sobre jóias e temas afins. Já o lado português, os temas vinham mais ligados a hábitos e tradições religiosas.

Marcel, assim como Munhoz, construiu uma estória composta por diversos "materiais", da mesma forma como se fabrica uma jóia falsa. Montou uma biografia escudada na santidade para impressionar Maria Bráulia e conseguir seus favores sexuais. Quanto à relação de Munhoz com o joalheiro Marcel, a cadeia associativa se estabelece pela ideologia do favor por conta da homossexualidade do juiz. As visitas de Munhoz à joalheria de Marcel para comprar presentes para seu amante, sempre vinham acompanhadas por um pedido de discrição. Em troca dessa discrição, o juiz lhe oferece a mulher como amante. $O$ pacto entre os três é selado no silêncio.

Por parte de Maria Bráulia o circuito se dá pela relação de obediência e submissão ao marido e ao amante, e pela relação de dominação sádica que estabelece com o sobrinho-secretário Julião e com a empregada Maria Preta. Por extensão, a cadeia se estende à Benedita, sobrinha de Maria Preta. Nesse caso a dominação é alicerçada na condição de classe e na herança escravocrata. A pulsão se manifesta no desejo sádico de se vingar no mais fraco, das agruras vividas. Dessa forma, Maria Bráulia faz do sobrinho seu capacho, sustentando a relação pela ambição deste na herança representada pelas suas jóias de família, principalmente no suposto rubi sangue de pombo que ela, cinicamente, sustenta como existente. Bráulia "amolava" sua mágoa com o marido, no sobrinho-secretário.

Entretanto, as relações não param e seguem entre Julião, a mulher Jurema e o amigo Bento. Julião, pela frustração de suas ambições na herança da tia, não consegue ter relações sexuais com Jurema e usa como desculpa as mesmas mentiras aprendidas com a tia que, por sua vez, aprendeu com o juiz e com o amante. Jurema, pela sua condição de mulher casada e submissa, demonstra sua inesgotável compreensão. Bento, comparsa de Julião no projeto escuso dos jogos eletrônicos, também repete a atitude de contrariedade do amigo. 
Com Maria Preta a dominação é garantida pela subserviência secularmente mantida, como afirma Pierre Legendre ${ }^{15}$, no amor ao censor, onde a pulsão encontra seu destino e gozo insaciável no prazer masoquista de servir. Acrescente-se a isso, o distanciamento hierárquico e social e a desconfiança de Maria Bráulia em relação à Maria Preta.

Maria Preta é como se fosse da família [...] uma vez que não é da família, é apenas como se fosse." "O dia está muito bonito e lá (na varanda) ficarão a salvo dos ouvidos de Maria Preta. Maria Preta é discreta mas não é surda; e o apartamento é pequeno. Um dia dona Brau me apareceu com os olhos de fogo e me foi falando quase aos gritos: "Quede meu cabochão de rubi? Quede ele. Eu nem sabia do que se tratava, eu fiquei de boca aberta [...] e foi a vez que ela me ofendeu muito, parecia que estava desconfiando de mim!"16.

Entretanto, a hierarquia e a dominação de classe costura a cumplicidade entre as duas e reforça o par sado-masoquista do amor ao censor.

Oh! Depois de tanto tempo! Com seu lindo rubi de tanajura no dedo dona Brau? Que é isso Preta? Quantas vezes já Ihe falei? Rat-na-pura! Do Sri Lanka, do Ceilão....Ah, ahn - Maria Bráulia ri com doçura e tolerância, muito divertida balançando a cabeça de lá para cá. Ahn, ahn - se ri também Maria Preta balançando igualmente a cabeça [....] como se o engano não fosse só seu mas das duas, uma terceira misteriosa entidade pela qual as duas zelassem juntas, que Ihes fosse preciosa por igual, e da qual falassem com igual complacência.. Estão com os rostos próximos, ambas com o olhar preso no anel de Maria Bráulia - atadas pelo pescoço por duas coleiras iguais, elos, cadeias de lembranças rolando para o passado $e$ as deixando ali agarradinhas naquele doce cacarejo, repetidoras ${ }^{17}$.

Está tudo dito, o ritual entre as duas reedita, sintomaticamente, a obediência e a submissão embutida naquele padrão de dominação.

Continuando o circuito pulsional a cadeia segue com Maria Preta e a sobrinha-neta afilhada Benedita. Seu gozo se exerce na tentativa de socialização. "Olha para seus pés. Xi se dona Altina visse isso! Meu Jesus! [...] Se quiser ficar na

\footnotetext{
15 Legendre, Pierre (1983). O amor do censor, ensaio sobre a ordem dogmática, Rio de Janeiro: Forense-Universitária: Colégio Freudiano.

${ }^{16}$ Tavares, Zulmira Ribeiro (2007). Op. cit., p. 8-9 e 68.

${ }^{17}$ Ibidem, p. 36.
} 
família. Dona Altina é de uma exigência!" E repete a lição bem aprendida expressa pelo sentimento elitista que internalizou afetivamente.

Se tem coisa que tira dona Brau do seu tirocínio é gentinha [...] se eu fosse explicar tudo que sei, nem dez anos bastavam, nem minha vida inteira. $E$ essas coisas de modos, de educação que eu quero passar para você, essas coisas então! Como já dizia dona Chiquinha tudo isso são também jóias de família esses ensinamentos. A gente herda, vem da mãe e do pai para os filhos ${ }^{18}$.

A cadeia significante com Benedita, é diferente, é por aí que entra abertamente o conflito de classe e, também, os ressentimentos e a inveja. Benedita diferente de Maria Preta se insurge à subordinação. Ironiza Maria Braúlia e deixa claro, para Maria Preta, que não pretende seguir sua trajetória. Não quer ficar na família. Benedita não quer dar continuidade à saga das Marias. As Marias da família eram chamadas pelo segundo nome, Francisca, Bráulia, Altina, no entanto, as Marias empregadas, eram chamadas por apelidos discricionários e estigmatizadores, como Russa, Preta, Só Maria. Benedita se nega a ser chamada de Dita, como ficou determinado pelas sinhazinhas. Benedita chegou nomeando a si própria de Bene. "No meu nome mando eu. Mexo eu!"

Por outro lado, Maria Bráulia não consegue disfarçar a insuportabilidade do gozo do outro e expressa sua inveja em relação a sensualidade e juventude de Benedita. "Aquela negrinha sonsa que só porque desbotou um pouco pensa que já é branca".

Maria Bráulia repara no seu traseiro duro e empinado, nas duas bolas que sobem e descem quando ela anda. Maria Altina vai ter que dar um jeito nisso pensa. Isso e lá derrière que se apresente numa sala? Vai ter de Ihe enfiar uma cinta, ou então um uniforme com saia larga, ou uma batina sobre.[...] $O$ pensamento na seqüência de operações a modificar a parte mais orgulhosa e independente de Benedita a reconforta muito" ${ }^{19}$.

Fechando a cadeia, voltamos ao falso anel de rubi. Este, simbolicamente, representa a falha do juiz. E coube a Maria Bráulia, sustentá-la. Não é por acaso que se chama Bráulia, o feminino de Bráulio, que na gíria, significa pau, pênis. No início

\footnotetext{
18 Ibidem, p. 69.

19 Ibidem, p. 39.
} 
da vida conjugal, a inocência de Braulinha juntamente com medo produzido pela autoridade patriarcal do marido, fez com que ela desenvolvesse um mecanismo de recusa, buscando justificativas pueris para os fatos vivenciados no seu cotidiano tais como: o casamento branco, o convívio com o amante do marido na própria casa, a descoberta da mentira sobre o anel de rubi etc. Com o passar dos anos e do processo de aprendizado, ela desempenhou com desenvoltura a arte da dissimulação e, cinicamente, encenou o enredo a ela determinado socialmente.

Já o cabochão (prego de cabeça grande), representava o pênis do amante. A referida jóia era um rubi legítimo e selou a relação amorosa. Aliás, plenamente justificada pelo direito canônico, como Ihe ilustrou Marcel. O casamento branco e estéril de Bráulia poderia ser anulado pelo Código Civil brasileiro, denominado ironicamente de Código Canônico, aludindo ao que Neder e Cerqueira Filho ${ }^{20}$ apontam como o "casamento" político-ideológico do direito romano canônico com os valores burgueses. Trata-se do erro essencial, previsto no Código Civil brasileiro, até hoje.

Considera-se erro essencial sobre a pessoa do outro cônjuge. - O que diz respeito à identidade do outro cônjuge, sua honra e boa fama, sendo erro tal, que o seu conhecimento ulterior torne insuportável a vida em comum ao cônjuge enganado ${ }^{21}$.

Ao presentear Braúlia, Marcel explicou-lhe que um rubi verdadeiro contém sempre uma inclusão, que é uma imperfeição, uma impureza provocada pelo trabalho da natureza e que qualifica um rubi como verdadeiro. A inclusão pode ser uma bolha, um canal, outro mineral como o rutílio, que é muito apreciado. As agulhas de rutílio quando estão agrupadas em vários pontos, produz um efeito estrela quando a luz bate na superfície lisa e abobadada da lapidação em cabochão. Assim, o homossexualismo do juiz representava uma inclusão no casamento branco de Bráulia. O que Marcel Ihe propõe é aproveitar essa inclusão para produzir um efeito. Um falo duro e viril representado pelo cabochão de rubi, coroado com um efeito estrela, velando assim o caráter sacramental do casamento, da família, da tradição, da perpetuação do poder, dos negócios, da política, da justiça e do decoro.

\footnotetext{
${ }^{20}$ Neder, Gizlene e Cerqueira Filho, Gisálio (2007). Idéias jurídicas e autoridade na família. Rio de Janeiro: Revan.

${ }^{21}$ Código Civil Brasileiro. Artigo 219 Caput, Parágrafo 1ํ․
} 
Segundo o Livro llustrado dos Símbolos, "as estrelas simbolizam luz e sabedoria a brilhar em meio à treva e à ignorância. Para muitas pessoas, são os espíritos dos mortos que subiram aos céus. Nos EUA, a estrela é distintivo de honra" ${ }^{22}$. Nesse sentido, enquanto significante mestre, o cabochão de rubi alude ao espectro do desejo sexual produzindo, simultaneamente, um efeito estrela a brilhar tanto no meio da treva, quanto a significar a honra masculina maculada pelo casamento branco de Bráulia.

\section{O engaste da ideologia na carona da contingência do desejo.}

Em Jóias de Família, a realidade perde sua plenitude pegajosa e remete a um amplo leque de significados, nesse sentido, o jogo realizado e encenado pelos personagens, para manter o segredo do casamento, não se limita simplesmente a mentiras e falsidades hipócritas. Acreditamos que o jogo aponta para a dialética da interpelação ideológica que guarda íntima relação com os sentimentos inconscientes. Por isso, partimos do pressuposto de que "toda análise social da ideologia remete ao imaginário e aos efeitos de ilusão/alusão [...] e que a questão do sujeito é constitutiva da instância ideológica, que, por sua vez, remete a problemática do inconsciente"23. Sendo assim, pensar, representar, sentir, emocionar-se são momentos da práxis tanto quanto agir. $O$ pensamento, as representações (metáforas e metonímias) e as formações discursivas, inclusive o discurso literário, são efetivamente formas de existência social. Entretanto, destacamos que a palavra é um logro e ao mesmo tempo o lugar da "verdade". Assim, enfatizamos que existem defasagens entre o sentir, o pensar e 0 agir que permite entender o discurso na sua dimensão ideológica. Não como pura ilusão, mas produzindo um efeito social específico. Neste caso, o efeito de ilusão é

\footnotetext{
${ }^{22}$ Bruce-Mitford, Miranda (2005). Livro ilustrado dos símbolos, São Paulo: Publifolha, p. 104.

${ }^{23}$ Cerqueira Filho, Gisálio (1988). Análise social da ideologia, São Paulo: EPU, p. 2-3.
} 
necessariamente uma alusão da ideologia. Melhor dizendo, o efeito da ilusão é uma das alusões da ideologia; uma, dentre outras.

A trama construída em "Jóias de Família" gira em torno da falsidade. Contudo, e esse é o ponto, o próprio jogo de lusco-fusco dos personagens alude ao significante mestre representado pelo cabochão. Este é o traço identificatório principal, embora, por deslocamento (efeito de ilusão), pareça ser o anel. No entanto, o cabochão produz um efeito mais contundente e significativo pelo que contém de fálico, inclusive em relação ao anel.

Sendo assim, queremos destacar como a ideologia permanece no plano do imediato, do aparecer social. Porém, a aparência do social não é algo falso e errado, mas é o modo como o processo social aparece para a consciência direta dos homens. Isto significa que uma ideologia sempre possui uma base real, só que essa base está de ponta-cabeça perpassada pela ideologia. Ou seja, o modo do social aparecer é ideológico. Não sendo pura inversão imaginária (até porque o imaginário existe), a ideologia tem uma representação simbólica que, guardando permanente relação com a realidade não-discursiva, aparece necessariamente como abstração e inversão. Segundo Marilena Chauí ${ }^{24}$, abstração é o conhecimento de uma realidade tal como se apresenta a nossa experiência imediata, como algo pronto e concluído, que não indagamos como foi concretamente produzida. Inversão é basicamente tomar o determinado pelo determinante; as conseqüências pelas premissas fundamentais.

Prosseguindo nosso argumento, acreditamos que o comportamento psíquico do indivíduo não é um simples reflexo passivo de conflito, mas uma forma ativa, ainda que mistificada, de resolvê-lo. O mesmo se pode dizer das ideologias, que não são meros subprodutos inertes das contradições sociais, mas estratégias habilidosas para contê-las, administrá-las e resolvê-las imaginariamente. A realidade, tal como a verdade, nunca é, por definição, toda. O que temos aqui é o paradoxo estrutural-dialético de um efeito (aparição espectral, fantasmagórica) que só existe para apagar as causas de sua existência. Nesse sentido, o indício pode ser lido como sintoma, seguindo a noção de repetição no pensamento de Freud. É

\footnotetext{
${ }^{24}$ Chauí, Marilena (1980). O que é ideologia, São Paulo: Brasiliense.
} 
nesse ponto que nos afastamos do indiciarismo de Ginzburg ${ }^{25}$ para nos aproximar da psicanálise. Trata-se de um diálogo entre indício e excesso. $\mathrm{O}$ excesso tomado como indício é o alvo do indiciarismo de base psicanalítica que nos inspira na análise da peça discursiva em questão. $O$ indício como sintoma, escorregadio, deslizante. Esse paradigma leva necessariamente aos domínios moleculares da sensibilidade, da inteligência emocional e do desejo. Portanto, incluí as emoções (contradição, ambivalência) que nos afetam na discussão do político e da ideologia.

Concordamos com Leyla Perrone-Moisés ${ }^{26}$ que "os psicanalistas sabem muito e os poetas sabem tudo". Ou seja, arte é uma forma de apreensão da realidade no que ela tem de dramático, trágico e belo, portanto, revela a humanidade. Nesse sentido, a peça literária, "Jóias de Família”, enquanto arte e, portanto, expressão do humano, permite analisar o papel da fantasia e da imaginação na construção da realidade. Ou melhor, o quanto de imaginação e de fantasia está a grudar e a moldar a nossa realidade circundante. Por isso, nossa ênfase na interpretação do referido romance é no quanto a ideologia se gruda justamente na fantasia. Por isso a realidade nunca é diretamente ela mesma, é sempre uma simbolização incompleta.

\section{As fantasias de poder e autoridade. Sofrimento e culpa: o casamento como sacramento.}

Na constelação de temas contidos em "Jóias de Família", temos o casamento e a família atraídos, como enfatiza $\mathrm{Neder}^{27}$, pelo princípio da perfeição e da representação das ideologias seculares num processo de apropriação cultural e atualização histórica. A representação fica então subordinada e vulnerável à tradição cristã de separar corpo e alma, soma e psique. O desconhecimento do próprio corpo é campo fértil para fantasias que podem acabar por produzir representações frágeis e até degradadas sobre o próprio corpo, campo aberto para as fantasias maníacas

\footnotetext{
${ }^{25}$ Ginzburg, Carlo. Op. cit.

${ }^{26}$ Perrone-Moisés, Leyla (2000). "Nenhures 2"; e "Lá nas campinas", In Inútil poesia e outros ensaios breves, São Paulo: Companhia das Letras.

${ }^{27}$ Neder, Gizlene (2000). Iluminismo jurídico-penal luso brasileiro: obediência e submissão, Rio de Janeiro: Freitas Bastos.
} 
forjadas em uma concepção onipotente do corpo, do absolutismo afetivo e da potencia da vontade. Nesse sentido, o personagem do juiz Munhoz é exemplar para abordamos a dor e o pathos produzidos por esse processo.

No simbolismo do romance o cisne de murano é mais um personagem, representa simbolicamente o juiz e, depois de sua morte, Maria Bráulia.

[...] Como uma imagem-tronco da qual as outras derivam ou para ela afluíam: sempre a mesa redonda com o pequeno lago polido no centro (habitada por uma única e solitária ave de indiscutível dignidade e cujo perfil Ihe lembrava vagamente o próprio juiz ao ler os jornais da manhã após o café $[\ldots]^{28}$.

Essa imagem é espetacular para expressar a autoridade construída na fantasia narcísica de perfeição com a qual o juiz se depara na morte. Nas suas reflexões antes de morrer, o juiz percebe que sua imaginação poderia ter sido mais bem empregada na sua profissão e também na sua vida particular. No entanto, a vanglória de mandar fez de sua vida uma prisão. O dolo e o decoro pautaram sua existência, sem que ele percebesse. A angústia dessa descoberta se dá com a proximidade da morte.

O juiz Munhoz ia e vinha pelo escritório, ia e vinha, mas não se decidia se em sua vida o dolo ou o decoro teria sobressaído. Ou apenas o decoro existiria para esconder o outro, o dolo, como se isso fosse possível $[. . .]^{29}$. (Tavares, 2007, p.58).

A última frase dita antes de morrer, "in dúbio pro reo", condensa dramaticamente a angústia da dúvida numa vida regida fortemente pela fantasia absolutista da vanglória de mandar, mas também e, sobretudo, pelo sofrimento (pathos) como expiação.

Maria Braúlia, depois da morte do juiz e do desaparecimento elegante do amante, trazia escondido sob o vestido, em algumas ocasiões, o cabochão de rubi. O cabochão representava um "escapulário, um bentinho, uma proteção para os aguilhões do remorso". Assim, acreditava manter a mensagem cifrada que, se revelada, perdia o poder da magia, da proteção imaginária. O rubi de cabochão, presente do amante, não era guardado no cofre, onde estava as jóias da família,

\footnotetext{
28 Tavares, Zulmira. Op. cit., p. 28.

${ }^{29}$ Ibdem, p. 58.
} 
lugar sagrado para o que representava o pecado. Por isso, não tinha lugar certo para ser guardado; ela mudava sempre de esconderijo e o movimentava pelo quarto como uma coisa viva, "quase um bichinho de estimação arrastado de lá para cá". Mais tarde, já na velhice, Maria Bráulia recorria ao cabochão para aplacar sua solidão de dupla viuvez.

É um rubi graúdo, de lapidação lisa, arredondada; um cabochão de rubi. Bom para ser segurado na concha da mão, fechando-se os dedos bem apertados em torno. Não machuca não tem arestas. Logo se aquece. Morno macio. Um bago. Uma gota de geléia de amora, uma gota de sangue com uma estrela de luz dentro. Uma maravilha ${ }^{30}$.

A culpa e o sofrimento cristão estão presentes o tempo todo nas atitudes dissimuladas dos personagens e nas metáforas que, por vezes, funcionam como metonímias. O juiz expressa sua culpa e sofrimento na angústia contida na máxima, "in dúbio pro reo". Maria Bráulia, no cabochão que transforma em bentinho para protegê-la do remorso. Marcel, na biografia escudada na santidade. Maria Preta na obediência vivida como missão. O círculo se fecha como no mito de ouroboros em que a serpente devora a própria cauda. Como bem resume Bilich (2005), a imagem da serpente engolindo a própria cauda atordoa a percepção de quem tenta encontrar o ponto de partida.

Desse modo, destacamos que quando as permanências ideológicas se soldam naquilo que é particular ou contingente, representa a pegada da ideologia, como nos informa Cerqueira Filho e Neder ${ }^{31}$. No caso de "Jóias de Família", o elemento permanente é o direito canônico que, via o escopo doutrinário da cristandade ocidental, se engasta no processo histórico particular da transformação capitalista no Brasil, resultando no "casamento" dos valores burgueses com os valores morais e religiosos do puritanismo católico romano. Este, representado pelo casamento como sacramento.

O juiz e Bráulia representam a burguesia emergente paulistana no plano econômico-social, com seus valores materiais e rituais de poder, conjugados ao

\footnotetext{
${ }^{30}$ Ibdem, p. 42.

${ }^{31}$ Cerqueira Filho, Gisálio e Neder, Gizlene (1997). Emoção e Política (a)ventura e imaginação sociológica para o século XXI, Porto Alegre: Sérgio A.Fabris.
} 
puritanismo católico. O casal vive o casamento como sacramento a despeito das circunstâncias que a realização do desejo impõe para ambos. Daí a culpa e o sofrimento. $\mathrm{O}$ registro de gozo dos personagens se dá no imaginário que organiza a vida social do casal e das relações familiares. O mecanismo de dominação da ideologia puritana do cristianismo romano interpela os personagens capturando suas subjetividades no curso da estória. Os afetos e os sentimentos na sua dimensão psíquica e social revelam, em última instância, a dimensão política do sofrimento (pathos). Por isso dissemos que uma ideologia pega, quando ela se gruda e floresce na plenitude da indeterminação do desejo. Na peça discursiva em questão, o registro de gozo se dá no imaginário. Este é constituído e conformado pelo absolutismo afetivo, a ideologia do favor, a vanglória de mandar, o casamento como sacramento, a representação da família nuclear burguesa e patriarcal, o controle da sexualidade e do desejo e pelo sofrimento como expiação. O imaginário comanda a ação e o efeito de inversão da ideologia, é tal, que a ilusão de controle da realidade domina a cena com estratégias e armadilhas, por parte dos personagens, gerando angústia e vulnerabilidade. Assim, o espectro da ideologia se repete sintomaticamente e atormenta o juiz levando-o a experimentar uma dúvida cruel no final de sua existência. Por outro lado, Bráulia é a própria caricatura bizarra da decadência, sem perder a posse, pois, afinal: "O juiz não the havia legado somente uma viuvez honrada, mas todo um estilo de vida". Entretanto, experimenta um gosto amargo.

Como se fabrica uma velha empertigada? "A velhice o tempo fornece. O empertigamento chega na corcova do mundo. Denteada como a crista dura de um velho réptil onde conforme o lugar de observação, os espinhos estão em cima ou embaixo. Aprender aos poucos.[.. ] um longo, duro aprendizado, ${ }^{\text {,32. }}$.

A imagem final de Bráulia é triste e melancólica. Comparada ao cisme de murano: "tão descorado se acha quanto um frango de pescoço torcido sem pinga de sangue. Um defuntinho de pé".

${ }^{32}$ Tavares, Zulmira (2007). Op. Cit., p. 60. 


\section{À guisa de conclusão}

É importante introduzir a distinção entre visão e olhar em psicanálise. O olhar está no campo pulsional (especular), do gozo, da subjetividade. A visão está no campo da percepção do escópico, daquilo que não se vê, mas sustenta aquilo que se vê. A virtude de Bráulia foi a prudência, Sua missão enquanto mulher casada foi zelar pela honra do marido como esposa perfeita e de acordo com o ideal tomista. Ou seja, baseado na obediência e submissão. Sua ilusão foi a de não transparecer nunca os segredos da família. Entretanto, onde a visão falta advém o olhar. Assim, embora a visão tente impedir o olhar, este especula e vê. Nesse sentido, podemos inferir que é pelo cisne de murano, representação simbólica que inicia e termina o romance, que o panóptico é simbolizado. É pelo seu olhar que entramos em contato com o reprimido, o não dito.

O efeito de ilusão produzido pela ideologia romano-cristã, alicerçada no casamento como sacramento, em "Jóias de Família", faz crer que tudo termina bem. Aparentemente, o destino dos personagens representa uma vitória da simulação. Entretanto, e esse é o ponto, é esse próprio destino que alude e denuncia e aquilo que impede o acesso ao desejo e causa dor e sofrimento.

A realidade só se apresenta através de sua simbolização incompleta. $O$ fantasma da culpa emerge justamente nessa lacuna que separa a realidade e o real e, em virtude da qual, a realidade tem o caráter de uma ficção. O fantasma dá corpo àquilo que escapa à realidade (simbolicamente estruturada). Como o limite entre a ficção e realidade é muito tênue, podemos dizer que a fantasia se gruda e molda a realidade, tanto no romance quanto na vida real. Por isso, o mecanismo analisado nessa ficção literária, diz respeito a todos nós. Revela nossa humanidade e o quanto as ideologias podem se grudar às nossas fantasias. Reconhecer esse poder é abrir caminho para o árduo e difícil trajeto a ser descoberto, por cada um, na incessante busca pela satisfação desse obscuro objeto chamado desejo, que reina soberano na sua incompletude.

\section{REFERÊNCIAS}


Berlinck, Manoel Tosta. (org.). (2005) Obssessiva neurose, São Paulo: Escuta.

Bilich, Jeanne (2005). As múltiplas trincheiras de Amylton de Almeida: o cinema como mundo, a arte como universo, Vitória: GSA Gráfica e Editora.

Bruce-Mitford, Miranda (2005). Livro ilustrado dos símbolos, São Paulo: Publifolha.

Cerqueira Filho, Gisálio (2005). Autoritarismo afetivo: a Prússia como sentimento, São Paulo: Editora Escuta.

. (2002). Édipo e Excesso. Reflexões Sobre Lei e Política, Porto Alegre: Sérgio Fabris Editor. . (1988). Análise social da ideologia, São Paulo: EPU.

Cerqueira Filho, Gisálio e Neder, Gizlene (1997). Emoção e Política (a)ventura e imaginação sociológica para o século XXI, Porto Alegre: Sérgio A.Fabris.

Chauí, Marilena (1980). O que é ideologia, São Paulo: Brasiliense.

Chevalier, Jean e Gheerbant, Alain (2005). Dicionário de símbolos, Rio e Janeiro: José Olympio.

Código Civil Brasileiro.

Ginzburg, Carlo (1989). Mitos, emblemas e sinais: morfologia e história, São Paulo: Companhia das Letras.

Lacan, Jaques (1988). Escritos, São Paulo: Editora Perspectiva. 
(1998) O seminário livro 11: os quatro conceitos fundamentais da psicanálise, Rio de Janeiro: Jorge Zahar Editor.

Legendre, Pierre (1983). O amor do censor, ensaio sobre a ordem dogmática, Rio de Janeiro: Forense-Universitária: Colégio Freudiano.

Neder, Gizlene e Cerqueira Filho, Gisálio (2007). Idéias jurídicas e autoridade na família. Rio de Janeiro: Revan.

Neder, Gizlene (2000). Iluminismo jurídico-penal luso brasileiro: obediência e submissão, Coleção Pensamento Criminológico, Rio de Janeiro: Freitas Bastos/ ICC.

Perrone-Moisés, Leyla (2000). Inútil poesia e outros ensaios breves, São Paulo: Companhia das Letras.

Philippe, Julien (2000). Abandonarás teu pai e tua mãe, Rio de Janeiro: Companhia de Freud.

Tavares, Zulmira Ribeiro (2007). Jóias de Família, Editora: Companhia das Letras.

Márcia Barros Ferreira Rodrigues

Professora da Universidade Federal do Espírito Santo

(Departamento de Ciências Sociais)

mbfrodrigues@ig.com.br 